International Review of Research in Open and Distributed Learning Volume 22, Number 2

May - 2021

\title{
Ready to Do OpenCourseWare? A Comparative Study of Taiwan College Faculty
}

Huei-Chuan Wei ${ }^{12}$ and Chien Chou $^{34}$

${ }^{1}$ Center for Institutional Research and Data Analytics, National Yang Ming Chiao Tung University, Taiwan; ${ }^{2}$ Center for Institutional Research and Data Analytics, National Chiao Tung University, Taiwan; ${ }^{3}$ nstitute of Education, National Yang Ming Chiao Tung

University, Taiwan; ${ }^{4}$ nstitute of Education, National Chiao Tung University, Taiwan

\begin{abstract}
This study aimed to address the teaching readiness issues of OpenCourseWare (OCW). Specifically, the research goal was to examine Taiwanese college faculty members' level of teaching readiness for OCW via a questionnaire named "Teaching Readiness Scale for OCW" (TRS-OCW). A total of 142 Taiwanese college faculty members both with and without OCW teaching experience participated in this study. The results showed that faculty members with OCW teaching experience had significantly higher readiness levels in the factors of perception of administrative support, personal characteristics, and OCW recognition when compared to faculty members without OCW teaching experience. Male faculty members with OCW teaching experience had higher readiness than female faculty members with OCW teaching experience in the OCW recognition factor. Moreover, the job position of OCW-experienced faculty did not make a difference in any readiness factor. Finally, perceived administrative support was the only significant predictor of the willingness of college faculty without OCW teaching experience to provide OCW in the future.
\end{abstract}

Keywords: teaching readiness; OpenCourseWare (OCW); college faculty; comparative study 


\section{Introduction}

With the increase in Internet use worldwide, many higher education institutions have come to view online learning as an alternative means to extending educational classrooms beyond their physical campuses (Barrett et al., 2009; Keramati et al., 2011; Lin \& Wang, 2018); particularly, to reduce the risk of COVID-19 infection, many schools have turned to distance education. Open education and its impact on the learning process have become remarkable and important, especially in higher education and adult education (Dhawan, 2020; Nahhas et al., 2018). Open education, such as open educational resources (OER), OpenCourseWare (OCW), and massive online open courses (MOOCs), allows people to access and participate in courses regardless of their time, physical and geographical barriers, and constraints. OCW is an important force in the global movement of open education (Sheu \& Shih, 2017). OCW is defined as "a free and open digital publication of high-quality educational materials, organized as a course" (Carson, 2009, p. 27). Since the Massachusetts Institute of Technology (MIT) initiated its OCW project in 2001 and inspired others to follow suit, more than 275 institutions around the world have joined the Open Education Consortium (OEC) to share their common values of openness, equity, collaboration, and multiculturalism (Open Education Consortium, n.d.). Of course, as in every educational movement, institutional OCW platforms differ from one another due to the unique educational settings and expectations of each institution.

While OCW has attracted millions of users around the world since its inauguration (MITOpenCourseWare, 2018), the major issue behind all institutional OCW is how to provide and maintain quality learning materials from educators to engage self-learners in continuous learning activities (Jaggars \& Xu, 2016; Paskevicius et al., 2018; Piedra et al., 2015; Rolfe, 2012). Past research has shown that teaching staff are the key to provide quality assurance in learning resources and learner support in OCW (Downes, 2007; Lowenthal et al., 2019; Paskevicius et al., 2018). Similarly, Wang et al. (2013) have pointed out that the degree of active participation of faculty in curriculum development could impact the success of OCW. If college faculty are to play such a critical role in OCW, as indeed they have up to now, it is essential to understand faculty members' teaching readiness for or abilities within OCW. By reaching such an understanding, we can identify strategies for training and provide support for faculty to engage in OCW.

However, only a small number of studies have explored whether college faculty are ready to participate in OCW. To better understand how to encourage college faculty to participate in OCW, it is necessary to identify the factors of OCW teaching readiness that faculty with past success have possessed. In undertaking this task, the present study aimed to examine the concepts and underlying factors of college faculty teaching readiness for OCW. By extending the previous study design and results, the present study also took related background factors and experience factors into consideration. 


\section{Literature Review}

\section{Teaching in Open Education}

Why do we need to discuss the instructors' teaching readiness in the open education context, especially in OCW? Are open education instructors' teaching methods different from traditional face-to-face teaching methods? Past researchers (e.g., Lowenthal et al., 2018; Paskevicius et al., 2018) have indicated that open pedagogies not only engage students with open culture literacies in the context of teaching and learning but also promote the production of knowledge and often integrate both formal and informal learning environments. Similarly, Hegarty (2015) pointed out that attributes of open teaching often include the use of participatory technologies, the encouragement of trust, the support of innovation and creativity, a greater sharing of ideas and resources, and reflective practice. In Zheng et al.'s (2016) study, the instructors further pointed out that participating in open education and sharing their pedagogies might have potential impacts on students, increase instructors' professional teaching growth, provide more research opportunities for instructors, and even further enhance instructors' reputations in education. Martin et al. (2019) stated that if online instructors were to teach successfully, additional competencies such as ICT competence or online instruction knowledge should be required. Besides online teaching competency, motivation should be another important issue in faculty's open teaching. Orr et al. (2009) proposed that the motivational factors influencing faculty members' participation in online teaching might relate to tenure, scholarship, promotion, etc. For example, in Orr et al.'s (2009) study, the interviewees indicated that the workload for designing learning materials and activities was a main concern. Moreover, these interviewees mentioned that if institutions could provide additional compensation for teaching an online course, they might consider teaching online or developing an online course. As noted in some of the aforementioned works, instructors' willingness and readiness are essential factors in the promotion and development of open education/classrooms in higher education.

\section{Teaching Readiness for OCW}

As OCW has become one of the most important types of open education, it is worthwhile discussing whether instructors or teachers are ready or have intentions to provide OCW. However, surprisingly few studies have been conducted on faculty readiness in OCW/MOOCs. For instance, Chou et al. (2011) interviewed eight Taiwanese college faculty members about their thoughts on and concepts of OCW and proposed eight possible factors influencing their participation in such a setting. The eight factors are (a) acceptance of the OCW concept, (b) the teacher's personal characteristics, (c) perceptions of self-ICT competency, (d) course materials, teaching methods, and styles, (e) effects on teaching and research, (f) administrative support and incentives, (g) intellectual property rights-related issues, and (h) interaction with OCW web users. Similarly, Wang et al. (2013) interviewed nine instructors who participated in the OCW and found that the key factors influencing them to participate included personal internal and external factors, organizational and 
administrative factors, and strategies for encouraging teachers to participate. This study further proposed that if teachers have more positive beliefs about OCW, they are more willing to participate in OCW and provide good quality teaching materials for students. Furthermore, Zheng et al. (2016) interviewed 14 MOOC instructors and proposed five key factors that instructors perceived might influence their willingness to teach MOOCs. These factors included: (a) struggling with managing collaborative work; (b) balancing the amount of time spent teaching the course; (c) maintaining realistic expectations; (d) dealing with critical students; and (e) having insufficient support. This study concluded that instructors should open their pedagogy and instructional approach and should offer new ways to conceptualize their practice of teaching and learning.

\section{Lessons Learned from Past Studies, Research Questions, and Significance of the Present Study}

The aforementioned small-scale interview studies serve a basis for large-scale investigations. In other words, the results of previous studies offer valuable insights, but more empirical evidence is needed. By scrutinizing all of the above studies, we tentatively identified some common factors of OCW teaching readiness: (a) personal characteristics (e.g., the perception of challenges in opening teaching); (b) perceived ICT self-efficacy (e.g., perception of personal technical competency); (c) perceived administrative or organizational support (e.g., the support from the teaching environment/instructional experts); and (d) perceived benefits of OCW (e.g., anticipated quality of OCW and general beliefs about OCW).

Moreover, since college faculty are definitely not a homogeneous group-there are differences in background as well as seniority-the present study considered Taiwan's higher education context and took two major factors, gender and position, into account in the investigation.

The research questions were as follows:

1. What are the differences in the OCW teaching readiness of college faculty members with different OCW experience?

2. Does the gender of college faculty members make any difference in their teaching readiness for OCW?

3. Does the position of college faculty members make any difference in their teaching readiness for OCW?

4. What is the relationship between college faculty members' OCW teaching readiness and their willingness to offer OCW? 
There are three significant aspects of this study. First, this study developed a college faculty teaching readiness scale for OCW (TRS-OCW) to conduct a large-sample survey and further identify the factors influencing faculty members' teaching readiness for OCW, especially in the Taiwanese context, as OCW is one of the major and popular types of open education in that country (Taiwan Open Course and Education Consortium, n.d.). Second, this study used different and appropriate statistical methods to analyze the collected data based on the research questions. Finally, by understanding college faculty members' teaching readiness for OCW, not only can instructional designers and faculty provide better OCW, but administrators and organizations can both help faculty enhance their OCW experiences and provide assistance to faculty willing to participate in OCW.

\section{Method}

\section{Research Participants and Distribution Process}

The participants in this study were Taiwanese college faculty who had provided OCW in the Taiwan Open Course and Education Consortium (TOCEC) and faculty who had not provided any OCW in the past. A total of 253 paper-and-pencil questionnaires were collected through two methods.

For college faculty who had provided OCW in the past, we collected the list of instructor members from the TOCEC website and mailed questionnaires to all of them (293). There were 120 questionnaires returned by mail, 49 of which had a substantial amount of missing data. As a result, only 71 valid surveys were completed.

For college faculty who had not provided any OCW in the past, we used purposive sampling and snowball sampling and mailed 176 questionnaires to them. There were 133 questionnaires returned by mail from faculty who had not provided any OCW in the past, with 62 having a substantial amount of missing data. Thus, there were 71 valid surveys completed.

The 142 valid questionnaires were examined for further 3-group comparisons. The effective respondent rate for this collection method was approximately 54\%. The response rate was somewhat low because participation was voluntarily, without enforcement or incentive.

As shown in Table 1, among the 142 participants, 94 (66.2\%) were men and 48 (33.8\%) were women; 71 (50.0\%) were from the OCW-experienced faculty group, 45 (31.7\%) were from the OCW-unexperiencedYes faculty group (faculty with no experience providing OCW but willing to provide OCW in the future), and 26 (18.3\%) were from the OCW-unexperienced-No faculty group (faculty with no experience providing OCW and not willing to provide OCW in the future). The average length of their teaching careers was 17.18

years, with 8.4 years as the standard deviation $(S D)$. Regarding faculty members' position, 61 (43.0\%) were professors, 45 (31.7\%) were associate professors, and 36 (25.4\%) were assistant professors/lecturers. 
Table 1

Demographic Characteristics of Participants

\begin{tabular}{|c|c|c|c|c|c|c|}
\hline & \multicolumn{2}{|c|}{$\begin{array}{l}\text { OCW- } \\
\text { experienced } \\
(n=71)\end{array}$} & \multicolumn{2}{|c|}{$\begin{array}{l}\text { OCW- } \\
\text { unexperienced-Yes } \\
(n=45)\end{array}$} & \multicolumn{2}{|c|}{$\begin{array}{l}\text { OCW- } \\
\text { unexperienced-No } \\
(n=26)\end{array}$} \\
\hline & $n$ & $\%$ & $n$ & $\%$ & $n$ & $\%$ \\
\hline \multicolumn{7}{|l|}{ Gender } \\
\hline Men & 48 & 67.6 & 29 & 64.4 & 17 & 65.4 \\
\hline Women & 23 & 32.4 & 16 & 35.6 & 9 & 34.6 \\
\hline \multicolumn{7}{|l|}{ Position } \\
\hline Professor & 35 & 49.3 & 18 & 40.0 & 8 & 30.8 \\
\hline Associate professor & 23 & 32.4 & 14 & 31.1 & 8 & 30.8 \\
\hline $\begin{array}{l}\text { Assistant } \\
\text { professor/Lecturer }\end{array}$ & 13 & 18.3 & 13 & 28.9 & 10 & 38.4 \\
\hline
\end{tabular}

Note. $N=142 . \mathrm{OCW}=$ OpenCourseWare.

\section{Instrument}

This survey was mainly composed of two sections. The first section investigated faculty members' demographic characteristics, including gender, position, teaching level, and past OCW experience. The second section measured the degree of faculty members' teaching readiness for OCW. To develop the selfreport questionnaires, the studies of Chou et al. (2011) and Wang et al. (2013) were reviewed, and other related studies (e.g., Paskevicius et al., 2018; Zheng et al., 2016) were taken into account to construct the item set.

Consequently, we developed a college faculty teaching readiness scale for OCW (TRS-OCW) containing 35 items for the second section. Among these 35 items, we categorized individual items into seven tentative factors, each designed to capture one construct: (a) acceptance of the OCW concept, (b) teachers' personal characteristics and perceptions of their own ICT competency, (c) course materials and teaching methods, (d) effects on teaching and research, (e) administrative support and incentives, (f) intellectual property rights-related issues, and (g) interaction with OCW web users. We deliberately removed the neutral level by using a four-point Likert scale ranging from 1 (strongly disagree) to 4 (strongly agree), thus requiring faculty to take a stance. A higher summed score indicated that faculty exhibited higher levels of teaching readiness for OCW. 


\section{Results}

\section{Exploratory Factor Analysis}

We used exploratory factor analysis (EFA) to recategorize these items into distinct factors and to ensure TRS-OCW construct validity (i.e., the deletion of invalid items). We performed the principal components of factor analysis with promax rotation to explore the underlying structure. If the value of the Kaiser-MeyerOlkin (KMO) measure of sampling adequacy is less than 0.5 , factor analysis should not be applied. In this study, the value of the KMO measure of sampling adequacy was 0.90, suggesting that applying factor analysis was appropriate.

Moreover, it was necessary for the chi-square of Bartlett's Test of Sphericity to be statistically significant in order to use factor analysis. In this study, the $p$-value of Bartlett's Test of Sphericity was o.oo $\left(\chi^{2}=\right.$ $4,957.832$ ). In the promax rotated factors, four factors were extracted with an eigenvalue greater than one, and they effectively explained $65.33 \%$ of the total variance. Eight items were deleted from the original 35 items owing to their low validity.

Thus, the final version of the TRS-OCW consisted of 27 items. The four factors were exactly interpreted as personal characteristics (PC), perception of administrative support (PAS), OCW recognition (OCWR), and competency in digital teaching material development (CDTMD).

Additionally, Cronbach's alpha reliability analysis was used to check the consistency of the scale items. Cronbach's alpha coefficient regarding the 27 items constituting the TRS-OCW was calculated as 0.94. Cronbach's alpha coefficient for personal characteristics, perception of administrative support, OCW recognition, and competency in digital teaching material development were calculated as $0.94,0.95,0.89$ and 0.79 , respectively. All variables had an alpha greater than 0.7 , and thus we concluded that the questionnaire was reliable (Cortina, 1993; Taber, 2018). Table 2 presents the values of each item in terms of mean, standard deviation, subscale reliability, and factor loading.

\section{Table 2}

Items and Factor Loadings of Four Factors on the TRS-OCW

\begin{tabular}{|c|c|c|c|c|}
\hline Item no. & Factor/items & $M$ & $S D$ & $\begin{array}{l}\text { Factor } \\
\text { loading }\end{array}$ \\
\hline \multicolumn{5}{|c|}{ Personal characteristics (PC) (Cronbach's $\alpha=0.94)$} \\
\hline $\mathrm{PC} 1$ & $\begin{array}{l}\text { Since my speaking is not fluent enough, I'm not willing } \\
\text { to have my teaching recorded and published on the }\end{array}$ & 3.21 & 0.56 & 0.98 \\
\hline
\end{tabular}




\begin{tabular}{|c|c|c|c|c|}
\hline Item no. & Factor/items & $M$ & $S D$ & $\begin{array}{l}\text { Factor } \\
\text { loading }\end{array}$ \\
\hline PC2 & $\begin{array}{l}\text { OCW website. } \\
\text { Since I have stiff body language while I lecture, I'm not } \\
\text { willing to have my teaching recorded and published } \\
\text { on the OCW website. }\end{array}$ & 3.22 & 0.53 & 0.97 \\
\hline $\mathrm{PC}_{3}$ & $\begin{array}{l}\text { Because I am not good looking, I'm not willing to have } \\
\text { my teaching recorded and published on the OCW } \\
\text { website. }\end{array}$ & 3.18 & 0.58 & 0.85 \\
\hline $\mathrm{PC}_{4}$ & $\begin{array}{l}\text { Because my teaching includes various strategies, I } \\
\text { think my teaching is not suitable to be recorded and } \\
\text { published on the OCW website. }\end{array}$ & 3.04 & 0.66 & 0.73 \\
\hline $\mathrm{PC}_{5}$ & $\begin{array}{l}\text { Because I do not want other colleagues to observe my } \\
\text { teaching, I'm not willing to offer an OCW. }\end{array}$ & 3.21 & 0.63 & 0.71 \\
\hline PC6 & $\begin{array}{l}\text { Because the content of my teaching materials is } \\
\text { sensitive, I think my lectures are not suitable to be }\end{array}$ & 3.15 & 0.62 & 0.70 \\
\hline $\mathrm{PC}_{7}$ & $\begin{array}{l}\text { published on the OCW website. } \\
\text { Because my blackboard-writing is not good enough, I'm } \\
\text { not willing to have my teaching recorded and } \\
\text { published on the OCW website. }\end{array}$ & 3.04 & 0.67 & 0.68 \\
\hline PC8 & $\begin{array}{l}\text { Because I significantly revise my teaching materials } \\
\text { every semester or every academic year, I think my }\end{array}$ & 2.95 & 0.67 & 0.67 \\
\hline & $\begin{array}{l}\text { teaching materials are not suitable to be published on } \\
\text { the OCW website. }\end{array}$ & & & \\
\hline PC9 & $\begin{array}{l}\text { Because I feel uncomfortable with having an open class, } \\
\text { I'm not willing to have my teaching recorded and } \\
\text { published on the OCW website. }\end{array}$ & 3.05 & 0.70 & 0.64 \\
\hline PC10 & I think I would need to spend more time to prepare & 2.88 & 0.78 & 0.58 \\
\hline
\end{tabular}




\begin{tabular}{|c|c|c|c|c|}
\hline Item no. & Factor/items & $M$ & $S D$ & $\begin{array}{l}\text { Factor } \\
\text { loading }\end{array}$ \\
\hline $\mathrm{PC} 11$ & $\begin{array}{l}\text { OCW materials, so I'm not willing to provide an } \\
\text { OCW. } \\
\text { I think my teaching methods (i.e., group discussion or } \\
\text { seminar) are not suitable to be recorded and } \\
\text { published on the OCW website. }\end{array}$ & 2.92 & 0.72 & 0.56 \\
\hline \multicolumn{5}{|c|}{ Perception of administrative support (PAS) (Cronbach's $\alpha=0.95$ ) } \\
\hline PAS1 & $\begin{array}{l}\text { If the school provides enough human resources to } \\
\text { support my OCW development, I'm willing to provide } \\
\text { an OCW. }\end{array}$ & 3.27 & 0.63 & 0.93 \\
\hline PAS2 & $\begin{array}{l}\text { If the school provides enough equipment and necessary } \\
\text { skills, I'm willing to provide an OCW. }\end{array}$ & 3.25 & 0.67 & 0.91 \\
\hline $\mathrm{PAS}_{3}$ & $\begin{array}{l}\text { If the school provides additional incentives (e.g., } \\
\text { bonuses) for me, I'm willing to provide an OCW. }\end{array}$ & 3.15 & 0.73 & 0.88 \\
\hline PAS4 & $\begin{array}{l}\text { If the school actively promotes the OCW, I'm willing to } \\
\text { provide an OCW. }\end{array}$ & 3.17 & 0.66 & 0.85 \\
\hline PAS5 & $\begin{array}{l}\text { If the school provides training courses (e.g., } \\
\text { workshops) for me, I'm willing to provide an OCW. }\end{array}$ & 3.13 & 0.72 & 0.83 \\
\hline PAS6 & $\begin{array}{l}\text { If the school provides sufficient funding for me, I'm } \\
\text { willing to provide an OCW. }\end{array}$ & 3.11 & 0.71 & 0.82 \\
\hline PAS7 & $\begin{array}{l}\text { Since there are significant benefits for my teaching } \\
\text { performance if I work on OCW development, I'm } \\
\text { willing to provide an OCW. }\end{array}$ & 3.14 & 0.80 & 0.78 \\
\hline PAS8 & $\begin{array}{l}\text { If my workload is reduced (i.e., reduction of teaching } \\
\text { hours) or the time spent developing an OCW can be } \\
\text { deducted from my teaching hours, I'm willing to }\end{array}$ & 3.40 & 0.66 & 0.67 \\
\hline
\end{tabular}




\begin{tabular}{|c|c|c|c|c|}
\hline Item no. & Factor/items & $M$ & $S D$ & $\begin{array}{l}\text { Factor } \\
\text { loading }\end{array}$ \\
\hline OCW recogn & $($ OCWR) (Cronbach's $\alpha=0.89)$ & & & \\
\hline OCWR1 & $\begin{array}{l}\text { I agree with the OCW principle of free education. All } \\
\text { courses should be provided to the public for free. }\end{array}$ & $3 \cdot 37$ & 0.80 & 0.94 \\
\hline OCWR2 & $\begin{array}{l}\text { I agree with the concept of open authorization provided } \\
\text { by OCW course material developers. All users should } \\
\text { be asked for nothing in return. }\end{array}$ & 3.23 & 0.85 & 0.88 \\
\hline $\mathrm{OCWR}_{3}$ & $\begin{array}{l}\text { I agree with the OCW principle of openness. Anyone } \\
\text { should be able to use the course materials freely. }\end{array}$ & 3.48 & 0.67 & 0.75 \\
\hline OCWR4 & $\begin{array}{l}\text { I agree with the delivery method of OCW. All courses } \\
\text { should be spread out and delivered via the Web. }\end{array}$ & $3 \cdot 31$ & 0.80 & 0.67 \\
\hline OCWR5 & $\begin{array}{l}\text { Because my knowledge and teaching materials are } \\
\text { valuable, I think they should not be free for all users. }\end{array}$ & 2.74 & 0.83 & 0.57 \\
\hline \multicolumn{5}{|c|}{ Competency in digital teaching material development (CDTMD) } \\
\hline \multicolumn{5}{|c|}{ (Cronbach's $\alpha=0.79$ ) } \\
\hline CDTMD1 & $\begin{array}{l}\text { I think I can learn how to produce digital teaching } \\
\text { materials by myself. }\end{array}$ & 2.90 & 0.73 & 0.76 \\
\hline CDTMD2 & $\begin{array}{l}\text { I think it is easy for me to produce digital teaching } \\
\text { materials by myself. }\end{array}$ & 2.44 & 0.84 & 0.70 \\
\hline CDTMD3 & $\begin{array}{l}\text { I am confident of my ability to produce digital teaching } \\
\text { materials. }\end{array}$ & 3.05 & 0.71 & 0.70 \\
\hline
\end{tabular}

Note. TRS-OCW = teaching readiness scale for OpenCourseWare; OCW = OpenCourseWare; $\mathrm{PC}=$ personal characteristics; PAS = perception of administrative support; OCWR = OpenCourseWare recognition; CDTMD $=$ competency in digital teaching material development. 


\section{Differences Among College Faculty Members' Readiness for OCW}

The first research question explored how college faculty members' teaching readiness for OCW varied across three different samples and stemmed from different levels of OCW experience/willingness. Table 3 presents the three groups' mean scores and $S D$ for the four factors. As shown in Table 3, whether faculty members in OCW-experienced group or OCW-unexperienced group, the average scores for each factor was higher than 2.5 point of a 4-point Likert scale.

\section{Table 3}

Results of a Multivariate Repeated One-Way ANOVA and Post Hoc Test of the TRS-OCW Regarding the Three Faculty Groups

\begin{tabular}{|c|c|c|c|c|c|c|}
\hline Group & Factor & $M$ & Range & $S D$ & $F$ & Post hoc \\
\hline \multirow[t]{5}{*}{ OCW-experienced } & $\mathrm{PC}$ & 3.24 & $3.11-3 \cdot 37$ & 0.55 & \multirow[t]{5}{*}{$16.04^{* * *}$} & \multirow{5}{*}{$\begin{array}{l}\text { PC, PAS, OCWR > } \\
\text { CDTMD; } \\
\text { PAS > PC }\end{array}$} \\
\hline & PAS & $3 \cdot 39$ & $3.25-3.53$ & 0.58 & & \\
\hline & & & & & & \\
\hline & OCWR & $3 \cdot 37$ & $3.22-3.52$ & 0.63 & & \\
\hline & CDTMD & 2.88 & $2.72-3.04$ & 0.67 & & \\
\hline OCW-unexperienced- & $\mathrm{PC}$ & 3.01 & $2.89-3.14$ & 0.41 & \multirow[t]{5}{*}{$11.39^{* * *}$} & \multirow{5}{*}{$\begin{array}{l}\text { PC, PAS, OCWR > } \\
\text { CDTMD; } \\
\text { PAS > PC }\end{array}$} \\
\hline \multirow[t]{4}{*}{ Yes } & PAS & 3.22 & $3.08-3.37$ & 0.48 & & \\
\hline & & & & & & \\
\hline & OCWR & 3.14 & $2.95-3.33$ & 0.64 & & \\
\hline & CDTMD & 2.76 & $2.59-2.94$ & 0.58 & & \\
\hline OCW-unexperienced- & $\mathrm{PC}$ & 2.75 & $2.60-2.90$ & 0.38 & $2.76^{*}$ & OCWR > PAS, \\
\hline \multirow[t]{3}{*}{ No } & PAS & 2.66 & $2.43-2.90$ & 0.58 & & \multirow[t]{3}{*}{ CDTMD } \\
\hline & OCWR & 2.98 & $2.71-3.24$ & 0.66 & & \\
\hline & CDTMD & 2.63 & $2.38-2.88$ & 0.62 & & \\
\hline
\end{tabular}

Note. $N=142$. ANOVA = analysis of variance; TRS-OCW = teaching readiness scale for OpenCourseWare; OCW = OpenCourseWare; PC = personal characteristics; PAS = perception of administrative support; OCWR = OpenCourseWare recognition; CDTMD = competency in digital teaching material development. ${ }^{*} p<.05$. ${ }^{* * *} p<.001$. 
To investigate the differences among the four factors of the scale, we conducted a one-way repeated analysis of variance (ANOVA). It is noted that the higher the mean score, the greater the weight or, in the case of this research, a higher mean indicated faculty members' perception of greater teaching readiness toward OCW. The results showed that in the OCW-experienced group and in the OCW-unexperienced-Yes group, the mean scores were significant $(F=16.04, p<.001 ; F=11.39, p<.001$, respectively). A post hoc test further revealed that the mean scores of PC, PAS, and OCWR were greater than the mean score of CDTMD, and that the mean score of PAS was greater than the mean score of PC in both groups. In addition, in the OCW-unexperienced-No group, the mean score was significant $(F=2.76, p<.05)$. A post hoc test further revealed that the mean score of OCWR was greater than the mean scores of PAS and CDTMD, respectively.

Further demonstration of the results is shown in Figure 1. The radar graphs for two faculty groups (OCWexperienced and OCW-unexperienced-Yes) have similar shapes but to different degrees across the four factors. On the other hand, the OCW-unexperienced-No group has a slightly different diamond shape and significantly lower degrees in all four factors.

\section{Figure 1}

Radar Chart for the Mean Comparison of the Four Factors for the Three Faculty Groups

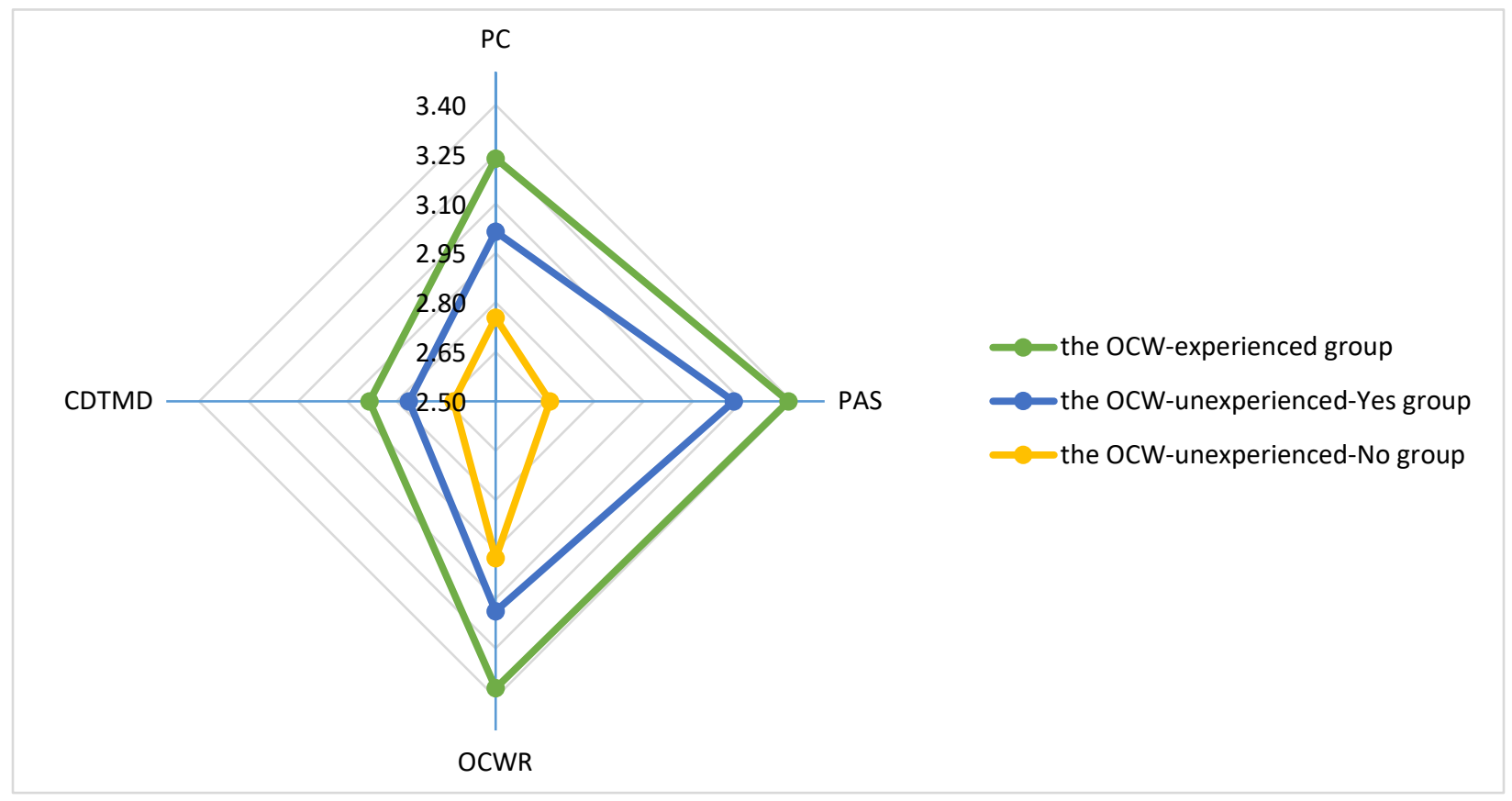

Note. OCW = OpenCourseWare; $\mathrm{PC}$ = personal characteristics; $\mathrm{PAS}=$ perception of administrative support; OCWR = OpenCourseWare recognition; CDTMD = competency in digital teaching material development. 
Moreover, to investigate the differences among the three groups in their TRS-OCW constructs, we conducted a one-way multivariate analysis of variance (MANOVA). As shown in Table 4, the results revealed that faculty members' experience with OCW made significant differences in the TRS-OCW $(F=5.03, p$ $<.001$; Wilks' $\left.\lambda=0.76 ; \eta^{2}=0.13\right)$. A follow-up analysis showed that in the factors of PC, PAS, and OCWR, the OCW-experienced group and the OCW-unexperienced-Yes group rated significantly higher than the OCW-unexperienced-No group. Only in the CDTMD factor, there were no significant difference among the three faculty groups with different OCW experience.

\section{Table 4}

Descriptive Statistics and One-Way MANOVA Results for Different Groups on TRS-OCW Factors

\begin{tabular}{|c|c|c|c|c|c|c|c|c|c|}
\hline & & & & & & & & & \\
\hline & & & & & & & & & Groups \\
\hline & $\exp$ & & unexpe & ed-Yes & unexp & ced-No & $F$ & $\eta^{2}$ & post \\
\hline & & & & & & & & & hoc \\
\hline & $M$ & $S D$ & $M$ & $S D$ & $M$ & $S D$ & & & \\
\hline $\mathrm{PC}$ & 3.24 & .55 & 3.01 & .41 & 2.75 & .38 & $10.33^{* * *}$ & 0.13 & $1>2>3$ \\
\hline PAS & 3.39 & .58 & 3.22 & .48 & 2.66 & .58 & $16.72^{* * *}$ & 0.19 & $1,2>3$ \\
\hline OCWR & 3.37 & .63 & 3.14 & .64 & 2.98 & .66 & $4.24^{*}$ & 0.06 & $1>3$ \\
\hline CDTMD & 2.88 & .67 & 2.76 & .58 & 2.63 & .62 & 1.65 & 0.02 & \\
\hline
\end{tabular}

Note: $N=142$. MANOVA = multivariate analysis of variance; $T R S-O C W=$ teaching readiness scale for OpenCourseWare; OCW = OpenCourseWare; PC = personal characteristics; $\mathrm{PAS}=$ perception of administrative support; OCWR = OpenCourseWare recognition; CDTMD = competency in digital teaching material development.

${ }^{*} p<.05 .{ }^{* * *} p<.001$.

\section{Gender Differences in College Faculty Members' Teaching Readiness for OCW}

For the second research question, we conducted an independent samples $t$-test to explore the differences between male and female faculty members across two different samples stemming from two groups with different OCW experience regarding the four measured factors of the TRS-OCW. In the OCW-experienced faculty group, the results revealed statistically significant gender differences in mean scores of OCWR $(t=$ 2.05, $p<.05$ ). As shown in Table 5 , male faculty members assigned a heavier weight to OCWR than did 
female faculty members. However, no significant gender differences were found in terms of the other three readiness factors.

Moreover, in the OCW-unexperienced faculty group, we merged the OCW-unexperienced-Yes group and OCW-unexperienced-No group to discuss the gender differences in each factor of the TRS-OCW. The results revealed statistically significant gender differences in the CDTMD mean scores $(t=3.38, p<.01)$. As shown in Table 5, male faculty members assigned a heavier weight to CDTMD than did female faculty members. However, no significant gender differences were found in terms of the other three readiness factors.

\section{Table 5}

Descriptive Statistics and t-Test of Gender on TRS-OCW Factors

\begin{tabular}{|c|c|c|c|c|c|c|}
\hline \multirow{3}{*}{ Factor } & \multicolumn{4}{|c|}{ OCW-experienced faculty $(n=71)$} & \multirow{3}{*}{$t$} & \multirow{3}{*}{ Cohen's $d$} \\
\hline & \multicolumn{2}{|c|}{$\operatorname{Men}(n=48)$} & \multicolumn{2}{|c|}{ Women $(n=23)$} & & \\
\hline & $M$ & $S D$ & $M$ & $S D$ & & \\
\hline $\mathrm{PC}$ & $3 \cdot 30$ & 0.58 & 3.11 & 0.45 & 1.40 & 0.37 \\
\hline PAS & 3.45 & 0.57 & 3.27 & 0.59 & 1.19 & 0.31 \\
\hline OCWR & 3.49 & 0.54 & 3.13 & 0.75 & $2.05^{*}$ & 0.55 \\
\hline \multirow[t]{4}{*}{ CDTMD } & 2.95 & 0.75 & 2.74 & 0.46 & 1.47 & 0.34 \\
\hline & \multicolumn{4}{|c|}{ OCW-unexperienced faculty $(n=71)$} & & \\
\hline & \multicolumn{2}{|c|}{$\operatorname{Men}(n=46)$} & \multicolumn{2}{|c|}{ Women $(n=25)$} & & \\
\hline & $M$ & $S D$ & $M$ & $S D$ & & \\
\hline $\mathrm{PC}$ & 2.97 & 0.48 & 2.83 & 0.25 & 1.58 & 0.37 \\
\hline PAS & 3.07 & 0.58 & 2.93 & 0.57 & 0.94 & 0.24 \\
\hline OCWR & 3.17 & $0.5^{8}$ & 2.91 & 0.74 & 1.62 & 0.39 \\
\hline CDTMD & 2.88 & 0.52 & 2.41 & 0.60 & $3 \cdot 38^{* *}$ & 0.84 \\
\hline
\end{tabular}

Note. $N=142$. TRS-OCW = teaching readiness scale for OpenCourseWare; OCW = OpenCourseWare; PC $=$ personal characteristics; PAS $=$ perception of administrative support; OCWR = OpenCourseWare 
recognition; CDTMD = competency in digital teaching material development.

${ }^{*} p<.05 .{ }^{* *} p<.01$.

\section{Position Differences in College Faculty's Readiness for OCW}

For the third research question, we conducted a one-way ANOVA to determine whether the position held by an OCW-experienced faculty member had a statistically significant effect on the mean scores of the four factors of the TRS-OCW. As shown in Table 6, OCW-experienced faculty members' position in universities did not change the ratings of the four factors in the TRS-OCW.

\section{Table 6}

Descriptive Statistics and One-Way ANOVA of OCW-Experienced Faculty Position Relative to TRS-OCW Factors

\begin{tabular}{lcccc}
\hline \multirow{2}{*}{ Factor } & $\begin{array}{c}\text { Professor } \\
\text { (n=35) }\end{array}$ & $\begin{array}{c}\text { Associate Professor } \\
(n=23)\end{array}$ & $\begin{array}{c}\text { Assistant Professor/Lecturer } \\
(n=13)\end{array}$ & $F$ \\
\cline { 2 - 4 } & $M(S D)$ & $M(S D)$ & $3(S D)$ & 3.08 \\
\hline PC & $3.39(0.47)$ & $3.09(0.62)$ & $3.06(0.51)$ & 0.44 \\
PAS & $3.33(0.65)$ & $3.48(0.46)$ & $3.38(0.59)$ & 3.05 \\
OCWR & $3.55(0.53)$ & $3.21(0.66)$ & $3.17(0.74)$ & 0.20 \\
\hline
\end{tabular}

Note. $n=71$. ANOVA = analysis of variance; TRS-OCW = teaching readiness scale for OpenCourseWare; OCW = OpenCourseWare; $\mathrm{PC}=$ personal characteristics; PAS = perception of administrative support; OCWR = OpenCourseWare recognition; CDTMD = competency in digital teaching material development.

In addition, as shown in Table 7, the OCW-unexperienced faculty members' position varied in the CDTMD factor $(F=4.39, p<.05)$ of TRS-OCW. A post hoc test further showed that faculty members with professor position rated CDTMD significantly higher than did faculty members with assistant professor/lecturer position. However, faculty members in different position did not express any significant differences regarding readiness in the factors of PAS, PC, and OCWR. 


\section{Table 7}

Descriptive Statistics and One-Way ANOVA of Position of OCW-Unexperienced Faculty Relative to TRSOCW Factors

\begin{tabular}{|c|c|c|c|c|c|}
\hline Factor & $\begin{array}{l}\text { Professor } \\
(n=26)\end{array}$ & $\begin{array}{c}\text { Associate } \\
\text { Professor } \\
(n=22)\end{array}$ & $\begin{array}{c}\text { Assistant } \\
\text { Professor/Lecturer } \\
(n=23)\end{array}$ & $F$ & Post hoc \\
\hline & $M(S D)$ & $M(S D)$ & $M(S D)$ & & \\
\hline PC & $3.06(0.51)$ & $2.86(0.37)$ & $2.82(0.29)$ & 2.36 & \\
\hline PAS & $3.10(0.67)$ & $3.09(0.48)$ & $2.85(0.54)$ & 1.39 & \\
\hline OCWR & $3.08(0.57)$ & $3.15(0.66)$ & $3.01(0.73)$ & 0.28 & \\
\hline CDTMD & $2.96(0.52)$ & $2.65(0.47)$ & 2.49 (o.69) & $4.39^{*}$ & $\begin{array}{l}\text { Professor > Assistant } \\
\text { Professor/Lecturer }\end{array}$ \\
\hline
\end{tabular}

Note. $n=71$. ANOVA = analysis of variance; TRS-OCW = teaching readiness scale for OpenCourseWare;

OCW = OpenCourseWare; PC = personal characteristics; PAS = perception of administrative support; OCWR = OpenCourseWare recognition; CDTMD = competency in digital teaching material development. ${ }^{*} p<.05$.

\section{OCW-Unexperienced College Faculty Members' Willingness to Offer OCW in the Future}

For the fourth research question on the relationship between college faculty members' teaching readiness and their willingness to offer OCW courses, we conducted a logistic regression analysis to determine which readiness factors could predict OCW-unexperienced faculty members' decision to provide OCW courses in the future. The sample of logistic regression analysis consisted of 71 faculty with no OCW experience, drawn from the main sample. Table 8 presents the predictability of the proposed model. The results show that the model correctly classified $93.3 \%$ of the faculty who are willing to provide OCW in the future and $57.7 \%$ of the faculty who are not willing to do so, with an overall accuracy of $80.3 \%$. This rate is acceptable for predicting faculty members' decision to provide OCW in the future $\left(\chi^{2}[4,71]=20.276, p<.001\right.$, Nagelkerke $\left.R^{2}=0.34\right)$. 


\section{Table 8}

Accuracy of a Model to Predict Willingness to Provide OCW in Future

\begin{tabular}{lccc}
\hline & Proposed model & Actual & $\begin{array}{c}\text { Accuracy of } \\
\text { model (\%) }\end{array}$ \\
\hline Willing to provide OCW & 42 & 45 & 93.3 \\
Not willing to provide OCW & 15 & 26 & 57.7 \\
\hline Average accuracy & & 71 & 80.3 \\
\hline
\end{tabular}

Note. $n=71 . \mathrm{OCW}=$ OpenCourseWare.

Table 9 presents the logistic regression coefficient (B), standard error (SE), Wald test, and odds ratio for each of the predictors. The results show that the PAS is a significant predictor. Based on the results obtained here, it could be concluded that the perceived administrative support of OCW-unexperienced faculty members is a significant predictor of their willingness to provide OCW in the future. It could be interpreted that OCW-unexperienced faculty members' decision about providing OCW would be related to their perception of the administrative support provided.

\section{Table 9}

Logit Coefficients and Wald Statistics of the Proposed Logistic Regression Model

\begin{tabular}{|c|c|c|c|c|c|c|}
\hline \multirow[b]{2}{*}{ Factor } & \multicolumn{6}{|c|}{ Choice of providing OCW in the future } \\
\hline & $B$ & $S E$ & $\begin{array}{l}\text { Odds } \\
\text { ratio }\end{array}$ & $95 \% \mathrm{CI}$ & Wald & $P$ value \\
\hline $\mathrm{PC}$ & -1.063 & .998 & .345 & {$[0.490,2.440]$} & 1.136 & .287 \\
\hline PAS & -2.387 & .779 & .092 & {$[0.020,0.423]$} & 9.380 & $.002^{* *}$ \\
\hline OCWR & .571 & .520 & 1.770 & {$[0.638,4.908]$} & 1.202 & .273 \\
\hline CDTMD & .534 & .581 & 1.705 & {$[0.546,5.322]$} & .844 & .358 \\
\hline
\end{tabular}

Note. $n=71$. OCW = OpenCourseWare; $\mathrm{PC}=$ personal characteristics; $\mathrm{PAS}=$ perception of administrative support; OCWR = OpenCourseWare recognition; CDTMD = competency in digital teaching material development.

${ }^{* *} p<.01$. 


\section{Discussion}

\section{Factors of College Faculty Teaching Readiness for OCW}

This study examined college faculty members' teaching readiness for OCW by using a college faculty teaching readiness scale for OCW (TRS-OCW) built on previous research and instruments. The EFA showed that the 27-item TRS-OCW included four factors of faculty teaching readiness: personal characteristics (PC), perception of administrative support (PAS), OCW recognition (OCWR), and competency in digital teaching material development (CDTMD).

Upon examining faculty members' mean scores for the TRS-OCW factors, both OCW-experienced faculty and OCW-unexperienced-Yes faculty exhibited the greatest weight in the readiness factors of administrative support and OCW recognition, followed by the factors of personal characteristics and competency in digital teaching material development. This result is consistent with Wang et al. (2013), whose results indicated that both organizational/administrative support and teachers' education approaches are crucial factors influencing teachers' willingness to participate in OCW. In sum, the faculty participants in this study, regardless of whether they had provided OCW before or were willing to provide it in the future, indicated their recognition of OCW and the importance of administrative support, and identified their personal characteristics. Moreover, whether or not faculty participants had OCW experience, they showed similar, relatively lower degrees of confidence in their ability to develop digital teaching materials.

In addition to the abovementioned findings, this study further examined the differences among three groups (OCW-experienced, OCW-unexperienced-Yes, OCW-unexperienced-No) in all factors of TRS-OCW. The findings revealed that OCW-experienced faculty rated higher in the factors of personal characteristics, administrative support, and OCW recognition than did OCW-unexperienced-Yes faculty and OCWunexperienced-No faculty. The reason might be that faculty who have OCW experience have confidence in their own teaching and more willingness to share their teaching/instruction with more online learners. In addition, the OCW-experienced faculty were fully aware of the benefits provided by administrations and organizations, such as reducing the number of teaching hours and providing teaching assistants. Furthermore, we found that OCW-unexperienced-Yes faculty rated higher in the readiness factors of personal characteristics and perception of administrative support than did OCW-unexperienced-No faculty. It may be that although these faculty members had no experience providing OCW, they were more confident about facing a camera and opening their minds to sharing their teaching with online learners. Additionally, the OCW-unexperienced-Yes faculty might have considered administrative support as helping and encouraging them to provide OCW. It is worth noting that no significant difference was found among the three faculty groups in the factor of competency in digital teaching material development. In order words, whether or not faculty members had OCW experience, they had equal perception of their competence and ability to develop digital teaching material for OCW. 


\section{Gender Differences in College Faculty Members' Teaching Readiness for OCW}

The second research question asked whether faculty members' gender made any difference in teaching readiness for OCW. The current study found that male faculty members with OCW experience exhibited statistically significantly greater teaching readiness in the factor of OCW recognition than did female faculty members with OCW experience. A possible explanation may be that male faculty members with OCW experience might agree more with OCW's model of openness, lack of cost to learners, and shared course materials and instruction in courses. Moreover, male faculty members lacking OCW experience exhibited statistically significantly greater readiness in the factor of competency in digital teaching material development than did female faculty members with OCW experience. This finding is consistent with the findings of previous studies (e.g., Broos, 2005; Wu \& Tsai, 2006) that men have better Internet self-efficacy than women. In other words, in this study, male faculty in general, and those with no OCW experience in particular, may be more confident in their ability to develop digital teaching materials than female faculty are. However, this significant difference between men and women disappeared in the OCW-experienced group. Both male and female faculty members in this study who had experience in providing OCW had equal competence levels in developing digital teaching materials for OCW.

\section{Position Differences in College Faculty Teaching Readiness for OCW}

Job position seemed to be associated with differences in college faculty teaching readiness for OCW. In the current study, we conducted a series of post hoc tests and found that OCW-experienced faculty with different position in universities did not have differences in any factors for OCW. In other words, no matter which position these experienced faculty members held, they were equally ready to teach OCW across the four measurement factors. In contrast, we found that OCW-unexperienced faculty with professor position exhibited a higher degree of competency in digital teaching material development than did those with assistant professor/lecturer position. The reason for this might be that when compared to junior faculty, professors with tenure-track position have less pressure to conduct research or seek promotions; they might have more time to explore different teaching methods or strategies and demonstrate more confidence in developing digital teaching materials. However, competence in digital material development, especially for professors, did not necessarily transfer to their possible development of OCW.

\section{OCW-Unexperienced College Faculty Willingness to Offer OCW in the Future}

Research question 4 concerns the relationship between faculty members' willingness to offer OCW in the future and their readiness factors. We conducted a logistic regression analysis and found that the administrative support factor was a statistically significant predictor of OCW-unexperienced faculty members' willingness to provide OCW in the future. In other words, the perception of administrative support is the only single readiness factor that contributes to OCW-unexperienced faculty members' 
decision-making process in providing future OCW. The result implies that OCW-unexperienced faculty are more likely to provide OCW in the future once they perceive administrative support from their universities.

\section{Conclusions, Limitations, and Future Research}

In conclusion, this study makes a contribution to both the OCW literature and to the practice of OCW promotion. The findings of this study have important implications for understanding factors that determine the OCW teaching readiness of college faculty. To encourage college faculty members, especially those without any OCW experience, to participate in OCW in the future, the most important factor is sufficient administrative support from higher educational institutions and OCW administrators. Possible strategies include increasing course development subsidies and decreasing regular teaching hours. Other strategies, such as enhancing faculty familiarity with OCW by sharing the concept of OCW and helping faculty solve ICT-related problems by providing assistants to prepare digital course materials or professional teams to help with postproduction, may also help.

Although this study provided relevant data and sought to answer research questions previously outlined by other studies (e.g., factors which affect instructor's participation in OCW), there were several limitations that prevented the study from being more generalizable. One main limitation of this study is the low response rate. We tried our best to solicit participation from all faculty members who have provided OCW in the TOCEC and then solicit matching response rates from faculty without OCW experience. Although the number of participants was sufficient for the present study's statistical analysis, more participants may be needed for future studies using different analysis methods.

Since MOOCs are getting more attention around the world, another recommendation is to expand this study to involve instructors or college faculty who have provided MOOCs and those who have not. Including the perspectives of both full-time faculty members and other instructors allows researchers to conduct a gap analysis to determine if there are overlaps with this study's findings.

The economic recession, layoffs, lockdown measures, and the risk of illness caused by COVID-19 mean selfemployment, remote jobs, and online learning have become very popular (Law, 2021). Schools need to shift face-to-face teaching to online teaching during the COVID-19 outbreak; faculty who have abilities or readiness to teach online become important, especially in higher education. According to the findings of this study, the administration should provide enough supports, such as incentives or technicians, when instructors prepare their online teaching. Information gathered from this research would allow a holistic view of OCW and MOOCs from the perspective of both OCW-experienced faculty and OCW-unexperienced 
faculty that could provide important breakthrough ideas for enhancing and promoting OCW and MOOCs in higher education. 


\section{References}

Barrett, B. F. D., Grover, V. I., Janowski, T., van Lavieren, H., Ojo, A., \& Schmidt, P. (2009). Challenges in the adoption and use of OpenCourseWare: Experience of the United Nations University. Open Learning: The Journal of Open, Distance and e-Learning, 24(1), 31-38. https://doi.org/10.1080/02680510802627803

Broos, A. (2005). Gender and information and communication technologies (ICT) anxiety: Male selfassurance and female hesitation. CyberPsychology \& Behavior, 8(1), 21-31. https://doi.org/10.1089/cpb.2005.8.21

Carson, S. (2009). The unwalled garden: Growth of the OpenCourseWare consortium, 2001-2008. Open Learning: The Journal of Open, Distance and e-Learning, 24(1), 23-29. https://doi.org/10.1080/02680510802627787

Chou, C., Hung, M.-L., \& Wei, H.-C. (2011, November). Are you ready to open your classroom? Taiwan college faculty's attitudes toward and concerns about OCW [Paper presentation]. 3rd Asia Regional OpenCourseWare and Open Education Conference 2011 (AROOC 2011), Meiji University, Tokyo, Japan. http://www.jocw.jp/AROOC2011/papers/paper_6.pdf

Cortina, J. M. (1993). What is coefficient alpha? An examination of theory and applications. Journal of Applied Psychology, 78(1), 98-104. https://doi.org/10.1037/0021-9010.78.1.98

Dhawan, S. (2020). Online learning: A panacea in the time of COVID-19 crisis. Journal of Educational Technology Systems, 49(1), 5-22. https://doi.org/10.1177/0047239520934018

Downes, S. (2007). Models for sustainable open educational resources. Interdisciplinary Journal of ELearning and Learning Objects, 3(1), 29-44. http://www.ijklo.org/Volume3/IJKLOv3po29044Downes.pdf

Hegarty, B. (2015). Attributes of open pedagogy: A model for using open educational resources. Educational Technology, 55(4), 3-13. https://upload.wikimedia.org/wikipedia/commons/c/ca/Ed Tech Hegarty 2015 article attrib utes of open pedagogy.pdf

Jaggars, S. S., \& Xu, D. (2016). How do online course design features influence student performance? Computers \& Education, 95, 270-284. https://doi.org/10.1016/j.compedu.2016.01.014 
Keramati, A., Afshari-Mofrad, M., \& Kamrani, A. (2011). The role of readiness factors in E-learning outcomes: An empirical study. Computers \& Education, 57(3), 1919-1929. https://doi.org/10.1016/j.compedu.2011.04.005

Law, T. J. (2021). Online teaching: Everything you need to know in 2021. Oberlo. https://www.oberlo.com/blog/online-teaching

Lin, Y.-J., \& Wang, H.-C. (2018). Using enhanced OER videos to facilitate English L2 learners' multicultural competence. Computers \& Education, 125, 74-85. https://doi.org/10.1016/j.compedu.2018.06.005

Lowenthal, P. R., Nyland, R., Jung, E., Dunlap, J. C., \& Kepka, J. (2019). Does class size matter? An exploration into faculty perceptions of teaching high-enrollment online courses. American Journal of Distance Education, 1-17. https://doi.org/10.1080/08923647.2019.1610262

Lowenthal, P. R., Snelson, C., \& Perkins, R. (2018). Teaching massive, open, online, courses (MOOCs): Tales from the front line. International Review of Research in Open and Distributed Learning, 19(3), 1-19. https://doi.org/10.19173/irrodl.v19i3.3505

Martin, F., Budhrani, K., Kumar, S., \& Ritzhaupt, A. (2019). Award-winning faculty online teaching practices: Roles and competencies. Online Learning, 23(1), 184-205. https://doi.org/10.24059/olj.v23i1.1329

MITOpenCourseWare (2018). Monthly reports. https://ocw.mit.edu/about/site-statistics/monthlyreports/MITOCW DB 2018 o9 v1.pdf

Nahhas, S., Bamasag, O., Khemakhem, M., \& Bajnaid, N. (2018, April). Linked data approach to mutually enrich traditional education resources with global open education [Paper presentation]. 2018 1st International Conference on Computer Applications \& Information Security (ICCAIS), Riyadh, Saudi Arabia. https://ieeexplore.ieee.org/document/8441941

Open Education Consortium (n.d.). About the open education consortium. https://www.oeconsortium.org/about-oec/

Orr, R., Williams, M. R., \& Pennington, K. (2009). Institutional efforts to support faculty in online teaching. Innovative Higher Education, 34(4), 257-268. https://doi.org/10.1007/s10755-0099111-6 
Paskevicius, M., Veletsianos, G., \& Kimmons, R. (2018). Content is king: An analysis of how the Twitter discourse surrounding open education unfolded from 2009 to 2016. The International Review of Research in Open and Distributed Learning, 19(1), 116-137. https://doi.org/10.19173/irrodl.v19i1.3267

Piedra, N., Jorge López, J. C., \& Tovar, E. (2015). Seeking open educational resources to compose massive open online courses in engineering education an approach based on linked open data. Journal of Universal Computer Science, 21(5), 679-711. https://doi.org/10.3217/jucs-021-05-0679

Rolfe, V. (2012). Open educational resources: Staff attitudes and awareness. Research in Learning Technology, 20. https://doi.org/10.3402/rlt.v20io.14395

Sheu, F.-R., \& Shih, M. (2017). Evaluating NTU's OpenCourseWare project with Google analytics: User characteristics, course preferences, and usage patterns. The International Review of Research in Open and Distributed Learning, 18(4), 100-122. https://doi.org/10.19173/irrodl.v18i4.3025

Taber, K. S. (2018). The use of Cronbach's Alpha when developing and reporting research instruments in science education. Research in Science Education, 48(6), 1273-1296. https://doi.org/10.1007/s11165-016-9602-2

Taiwan Open Course and Education Consortium (n.d.). Taiwan Open Course and Education Consortium. https://www.tocec.org.tw/web/about.jsp?about id=1

Wang, C.-H., Chen, C.-P., \& Hu, S.-Z. (2013). A case study of the factors affecting public university faculty's participation in OpenCourseWare. Journal of Educational Media \& Library Sciences, 51(1), 131-161. https://doi.org/10.6120/JoEMLS.2013.511/0566.RS.CM

Wu, Y.-T., \& Tsai, C.-C. (2006). University students' Internet attitudes and Internet self-efficacy: A study at three universities in Taiwan. CyberPsychology \& Behavior, 9(4), 441-450. https://doi.org/10.1089/cpb.2006.9.441

Zheng, S., Wisniewski, P., Rosson, M. B., \& Carroll, J. M. (2016, February). Ask the instructors: Motivations and challenges of teaching Massive Open Online Courses [Paper presentation]. CSCW'16: Computer Supported Cooperative Work and Social Computing, San Francisco, California, USA. https://doi.org/10.1145/2818048.2820082 
Ready to Do OpenCourseWare? A Comparative Study of Taiwan College Faculty Wei and Chou

Athabasca

University

(c) 